\title{
Analysis of E-Commerce Adoption Level on Culinary Micro, Small and Medium Enterprises (Umkm) in Karawang Regency Using Smart PLUS
}

\author{
Karya Suhada ${ }^{1}$ \\ Study Program \\ Technical Information \\ STMIK Rosma, Indonesia \\ Email: karya@rosma.ac.id
}

\author{
Lila Setiyani ${ }^{2}$ \\ Study Program \\ Information System \\ STMIK Rosma, Indonesia \\ Email: lila.setiyani@dosen.rosma.ac.id
}

\author{
Damas Setiadi Sukardi ${ }^{3}$ \\ Study Program \\ Technical Information \\ STMIK Rosma, Indonesia \\ Email: \\ damas.sukardi@mhs.rosma.ac.id
}

\begin{abstract}
E-commerce is an electronic trading tool where trading transactions, both buying and selling, are carried out electronically on the internet network. The existence of the internet and various technologies in the telecommunication sector have changed many things, one of which is in UMKM. The current owners of UMKM are expected to be able to compete and maintain the continuity of their business by making changes and applications in the technical field. This study aims to analyze the level of e-commerce adoption in culinary UMKM in Karawang Regency. The method used is a qualitative approach by measuring technology, environmental, organizational, and e-commerce adoption variables on the performance of UMKM. The data collection technique used in this study was probability sampling, with random sampling types, with a total of 70 culinary UMKM in Karawang regency. The results of this study indicate that technology and environmental factors have a positive effect on the adoption of e-commerce so that they can improve the performance of the UMKM in this study.
\end{abstract}

Keywords - E-Commerce Adoption, Performance of UMKM, UMKM

Abstrak - E-commerce merupakan alat perdagangan elektronik dimana transaksi perdagangan, baik jual beli, dilakukan secara elektronik di jaringan internet. Keberadaan internet dan berbagai teknologi di bidang telekomunikasi telah mengubah banyak hal, salah satunya di bidang UMKM. Para pemilik UMKM saat ini diharapkan mampu bersaing dan menjaga kelangsungan usahanya dengan melakukan perubahan dan aplikasi di bidang teknis. Penelitian ini bertujuan untuk menganalisis tingkat adopsi ecommerce pada UMKM kuliner di Kabupaten Karawang. Metode yang digunakan adalah pendekatan kualitatif dengan mengukur variabel adopsi teknologi, lingkungan, organisasi, dan e-commerce terhadap kinerja UMKM. Teknik pengumpulan data yang digunakan dalam penelitian ini adalah probability sampling, dengan jenis random sampling, dengan jumlah 70 UMKM kuliner di Kabupaten Karawang. Hasil penelitian ini menunjukkan bahwa faktor teknologi dan lingkungan berpengaruh positif terhadap adopsi e-commerce sehingga dapat meningkatkan kinerja UMKM dalam penelitian ini.

Kata Kunci-Adopsi E-Commerce, Kinerja UMKM, UMKM

\section{INTRODUCTION}

The development of technology at this time is very rapid, a business is required to utilize existing technology to run its business. One of the technological developments is in the business sector. Currently, business owners are required to keep up with technological developments, because along with technological developments, traditional markets are being displaced by technology which in this case is ecommerce. According to Kuswiratmo (2016:163) Electronic Commerce (E-Commerce) or better known as Online Shopping is the implementation of commerce in the form of sales, purchases, orders, payments, and promotions of a product of goods and/or services carried out by utilizing computers and electronic communication facilities [1]. digital or data telecommunications. In addition, this form of commerce can also be carried out globally, namely by using the internet network [2].

It is undeniable that the development of information technology has had an impact on commercial activities. The existence of the internet and various technologies in the telecommunications sector have changed many things. UMKM are expected to be able to compete and maintain business continuity by making changes and implementation in the technical field. According to the State Ministry of Cooperatives and Small and Medium Enterprises (Menegkop and UKM), what is meant by Small Business (UK), including Micro Enterprises (UMI), is a business entity that has a net worth of at most Rp. 200,000,000, excluding land and building a place of business, and having annual sales of a maximum of Rp. 1,000,000,000. Meanwhile, medium-sized enterprises (UM) are business entities owned by Indonesian citizens who have a net worth of more than Rp. 200,000,000 to Rp. 200,000,000. IDR 10,000,000,000, excluding land and buildings [3].

Karawang Regency has a variety of UMKM. In November 2020 , there were 87,574 UMKM actors registered in the Karawang district [4]. By looking at the number of researchers interested in analyzing the level of adoption of eCommerce in Kulimer UMKM in Karawang district to find out the benefits of e-commerce for UMKM owners and to know the technological capabilities and levels of e-commerce 
adoption. The e-commerce referred to in this study is the use of go-food applications which are now increasingly being discussed as a means or activity of a business. The use of the go-food application is growing rapidly because in addition to making it easier for customers to find what food they want, it also makes it easier for business actors to make sales. The results of this study provide strategic knowledge and information regarding the adoption of e-commerce in culinary UMKM in Karawang district [5].

\section{METHOD}

\section{A. Types of Research}

The research method used in this research is quantitative research. According to Sugiyono (2011:8) [6], quantitative is a research method based on the philosophy of positivism, used to examine certain populations or samples, data collection using research instruments, data analysis is quantitative/statistical, with the aim of testing predetermined hypotheses. . Meanwhile, according to Borg and Gall (1989) in quantitative research, causal relationships between variables are detected, then the observed information from the sample is obtained through statistical data collection. The data collected were analyzed in numerical form [7][8].

\section{B Research Population}

According to Suharsimi (1998:117) in [7] explained that the population is the whole object to be studied. Meanwhile, according to Sugiyono (2010) [9] the population is a generalization area consisting of objects or subjects that have certain characteristics and qualities that have been determined by a researcher to be studied and then conclusions will be drawn. The population in this study is UMKM in the culinary field in Karawang Regency.

\section{RESULTS AND DISCUSSION}

The following is a recapitulation of the results of the questionnaire that researchers have distributed to Culinary UMKM in Karawang Regency, amounting to 75 respondents.

TABLE 1. RECAPITULATION OF QUESTIONNAIRE RESULTS

\begin{tabular}{|c|c|c|c|c|c|c|}
\hline \multirow{4}{*}{ Variable } & \multirow{5}{*}{ Code } & \multicolumn{4}{|c|}{ Questionnaire Answer } \\
\cline { 2 - 7 } & & STS & TS & $\mathbf{N}$ & $\mathbf{S}$ & $\mathbf{S S}$ \\
\hline \multirow{4}{*}{$\begin{array}{c}\text { Technology } \\
\text { (TN) }\end{array}$} & TN1 & 0 & 1 & 10 & 21 & 43 \\
\cline { 2 - 7 } & TN2 & 0 & 1 & 12 & 25 & 37 \\
\cline { 2 - 7 } & TN3 & 0 & 3 & 17 & 23 & 32 \\
\cline { 2 - 7 } & TN4 & 2 & 1 & 17 & 22 & 33 \\
\hline \multirow{4}{*}{$\begin{array}{c}\text { Organizational } \\
\text { (OR) }\end{array}$} & OR1 & 0 & 2 & 17 & 28 & 28 \\
\cline { 2 - 7 } & OR2 & 1 & 3 & 20 & 27 & 24 \\
\cline { 2 - 7 } & OR3 & 0 & 4 & 12 & 20 & 39 \\
\cline { 2 - 7 } & OR4 & 0 & 1 & 15 & 17 & 42 \\
\hline \multirow{4}{*}{$\begin{array}{c}\text { Environment } \\
(\text { LK) }\end{array}$} & LK1 & 1 & 2 & 10 & 27 & 35 \\
\cline { 2 - 7 } & LK2 & 2 & 4 & 17 & 26 & 26 \\
\cline { 2 - 7 } & LK3 & 0 & 0 & 15 & 25 & 35 \\
\cline { 2 - 7 } & LK4 & 2 & 4 & 18 & 26 & 25 \\
\hline
\end{tabular}

\begin{tabular}{|c|c|c|c|c|c|c|}
\hline \multirow{4}{*}{$\begin{array}{c}\text { E-Commerce } \\
\text { Adoption } \\
\text { (AC) }\end{array}$} & $\mathrm{AC} 1$ & 0 & 0 & 5 & 23 & 47 \\
\cline { 2 - 7 } & $\mathrm{AC} 2$ & 0 & 1 & 8 & 30 & 36 \\
\cline { 2 - 7 } & $\mathrm{AC} 3$ & 1 & 0 & 9 & 23 & 42 \\
\cline { 2 - 7 } & $\mathrm{AC} 4$ & 1 & 1 & 14 & 35 & 24 \\
\cline { 2 - 7 } & $\mathrm{AC} 5$ & 1 & 0 & 13 & 33 & 28 \\
\cline { 2 - 7 } & $\mathrm{AC} 6$ & 0 & 1 & 6 & 23 & 45 \\
\cline { 2 - 7 } & $\mathrm{AC} 7$ & 2 & 5 & 23 & 23 & 22 \\
\hline \multirow{4}{*}{$\begin{array}{c}\text { Performance } \\
\text { UMKM (KN) }\end{array}$} & 0 & 4 & 17 & 27 & 27 \\
\cline { 2 - 7 } & $\mathrm{KN} 1$ & 0 & 4 & 18 & 31 & 22 \\
\cline { 2 - 7 } & $\mathrm{KN} 2$ & 0 & 0 & 22 & 34 & 19 \\
\hline
\end{tabular}

Additional Information :

STS : Strongly Disagree

TS : Do Not Agree

$\mathrm{N} \quad$ : Neutral

$\mathrm{S}$ : Agree

SS : Strongly Agree

\section{Data Analysis Results}

The data processing used in this research is using SmartPLS. In the results of this analysis, validity and reliability tests were carried out. The structural model in this study can be seen in the image below.

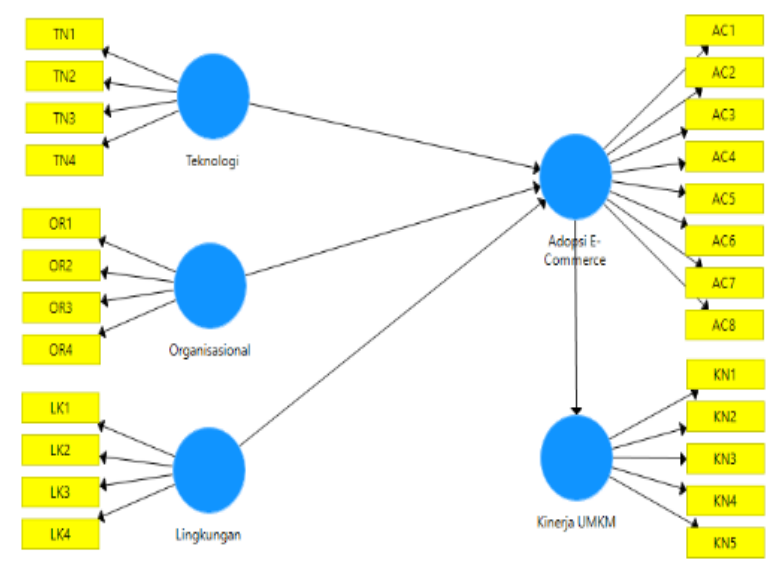

Fig.1 Structural Model

\section{A. Validity Test}

In the validity test, the indicator is considered valid if it has an outer loading value of the variable dimension having a loading value $>0.7$ so it can be concluded that the measurement meets the criteria for convergent validity. The output generated by SmartPLS for outer loading is as follows [10].

TABLE 2. OUTER LOADING RESULTS 

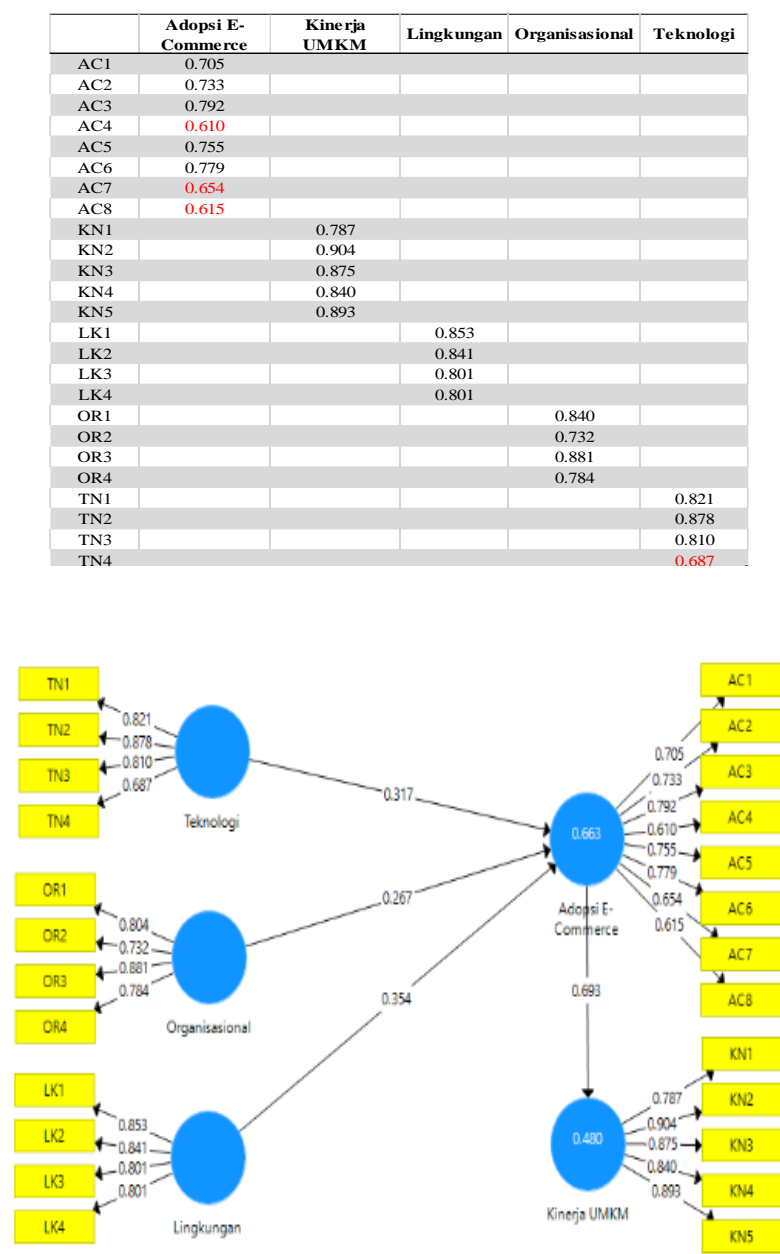

Figure 2. Outer Loading Value

The results of the outer loading test in table 4.6 or figure 4.6 show that there are still invalid indicators marked in red. Invalid indicators are AC4 with a value of $0.60, \mathrm{AC} 7$ with a value of 0.654 , AC8 with a value of 0.615 and TN4 with a value of 0.87 . The condition for proceeding to the next stage is that the outer loading value must be valid, so that the outer loading test will be carried out again by removing / eliminating the previously invalid indicators. The results of the outer loading test can then be seen in the table below.

\section{B. Reliability Test}

The reliability test was carried out by looking at the composite reliability value. If the correlation value is more than 0.7 then it is said that the item provides a sufficient level of reliability, on the contrary if the correlation value is below 0.7 then the item is said to be less reliable.

TABLE 3. COMPOSITE RELIABILITY VALUE

\begin{tabular}{|l|c|}
\hline & Composite Reliability \\
\hline E-commerce adoption & 0.901 \\
\hline UMKM Performance & 0.934 \\
\hline Environment & 0.894 \\
\hline Organizational & 0.788 \\
\hline Technology & 0.901 \\
\hline
\end{tabular}

The table above shows that the correlation value of the composite reliability value for all constructs is above the value of 0.7 . With the resulting value, all constructs have good reliability in accordance with the minimum value limit that has been required.

To strengthen the results of the reliability test, the reliability test can be carried out with Cronbach's Alpha with the recommended value of 0.6. The table below shows that the Cronbach's Alpha value on all constructs has met the requirements, which are above 0.6.

TABLE 4. CRONBACH'S ALPHA

\begin{tabular}{|l|c|}
\hline & Cronbach's Alpha \\
\hline E-commerce adoption & 0.862 \\
\hline UMKM Performance & 0.912 \\
\hline Environment & 0.843 \\
\hline Organizational & 0.814 \\
\hline Technology & 0.833 \\
\hline
\end{tabular}

\section{Evaluation of the Structural Model (Inner Model)}

Structural model testing was conducted to see the relationship between the construct, the significance value and the $\mathrm{R}$ Square of the research model. The value of $\mathrm{R}$ Square is used to see the relationship between variables which is a goodnessfit model test. The value of R Square can be seen.

TABLE 5. R SQUARE VALUE

\begin{tabular}{|l|c|c|}
\hline & R Square & R Square Ajusted \\
\hline $\begin{array}{l}\text { E-commerce } \\
\text { adoption }\end{array}$ & 0.541 & 0.521 \\
\hline $\begin{array}{l}\text { UMKM } \\
\text { Performance }\end{array}$ & 0.429 & 0.421 \\
\hline
\end{tabular}

The table above shows that the E-Commerce Adoption variable has an R-square value of 0.541 which means that the technological, organizational and environmental variables affect the E-Commerce Adoption variable by $54.1 \%$ and the remaining $45.9 \%$ is influenced by other variables. While the UMKM Performance variable has an R-square value of 0.429 , which means that the E-Commerce Adoption variable affects the UMKM Performance variable by $42.9 \%$ and the remaining $57.1 \%$ is influenced by other variables.

\section{T-Statistic Value}

The following is a diagram of the t-statistical values based on the output generated by Smart PLS.

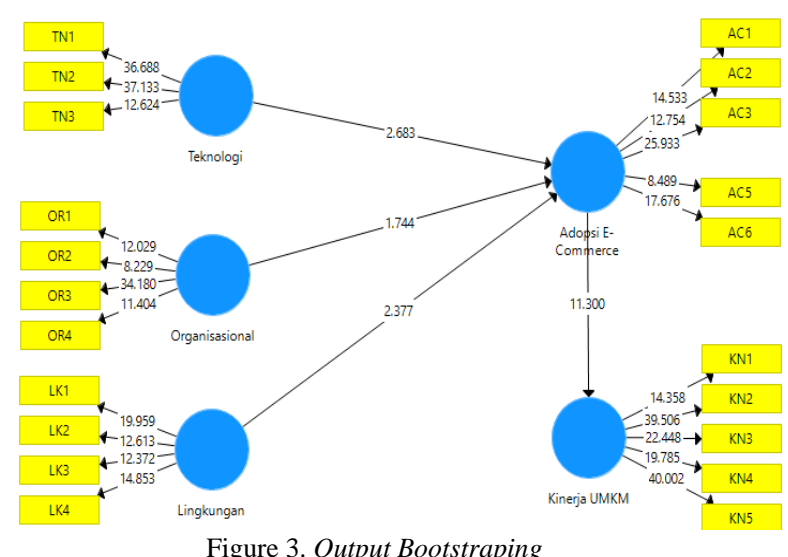

46 | Vol.2 No.2, July 2021 


\section{CONCLUSION}

Based on the results of the analysis that has been carried out, it can be concluded that the factors that influence the adoption of e-commerce UMKM in the culinary field are technological, organizational and environmental factors. Furthermore, to determine the relationship between variables, researchers tested the hypothesis. The results of this study indicate that :

Technological factors are proven to have a positive effect on E-commerce Adoption. This shows that the availability of information technology tools, the availability of programs and support systems, the suitability of benefits and costs, as well as the capabilities and skills of human resources in using e-commerce can encourage UMKM owners to use ecommerce in running their business. Organizational factors are not proven to have a positive effect on E-commerce adoption. This shows that the availability of financial resources, the readiness of UMKM owners to accept risks, leadership commitment and awareness of information technology developments do not encourage UMKM owners to use e-commerce in running their business. Environmental factors have been shown to have a positive effect on Ecommerce adoption. This shows that the demands and encouragement from consumers, suppliers, the development of the business world, and competitive pressure are able to encourage UMKM owners to use e-commerce in running their business. E-Commerce adoption is proven to have a positive effect on UMKM performance. This shows that ecommerce can facilitate access to information, improve business performance, improve quality and speed of service, improve cost efficiency, availability of facilities and infrastructure, keep up with technological developments, encouragement from external parties and support from all elements of e-commerce organizations can improve UMKM performance. such as increased productivity, increased sales, increased profits/profits, increased product innovation and increased UMKM innovation after using e-commerce.

\section{REFERENCES}

[1] B. Huda and B. Priyatna, "Penggunaan Aplikasi Content Management System (CMS) untuk Pengembangan Bisnis Berbasis E-commerce," Systematics, vol. 1, no. 2, pp. 81-88, 2019.

[2] Helmalia, "Pengaruh E-Commerce Terhadap Peningkatan Pendapatan Usaha Mikro Kecil Dan Menengah Di Kota Padang," JEBI (Jurnal Ekon. dan Bisnis Islam, vol. 3 No. 2, no. doi: 10.15548/jebi.v3i2.182, p. 237,2018

[3] N. E. Prastika and D. E. Purnomo, "Pengaruh Sistem Informasi Akuntansi Terhadap Kinerja Perusahaan Pada Usaha Mikro Kecil Dan Menengah (Umkm) Di Kota Pekalongan," J. LITBANG, vol. 4, no. 3, 2019.

[4] E. Kurniawati, "87.574 UMKM di Karawang Terdaftar Menerima BantuanModal,"Tempo.co,p.Available: https://metro.tempo.co/read/1404452/87-, 2020.

[5] S. S. Hilabi and B. Priyatna, "Pembangunan Profil Desa Berkelanjutan Sebagai Wujud Kuliah Kerja Nyata (Kkn) Berbasis Online (Studi Kasus Desa Karawang Kulon)," Pros. Konf. Nas. Penelit. DAN Pengabdi. Univ. BUANA PERJUANGAN KARAWANG, vol. 1, no. 1, pp. 1732-1746, 2021.

[6] Sugiyono, Metode Penelitian Kuantitatif, Kualitatif dan R\&D. Bandung: Alfabeta, 2011.

[7] W. R. Borg and M. D. Gall, "Educational Research: An Introduction, Fifth Edit,” New York and London: Longman, 1989.

[8] A. M. Siregar, S. Faisal, Y. Cahyana, and B. Priyatna, "Perbandingan Algoritme Klasifikasi Untuk Prediksi Cuaca," J. Account. Inf. Syst., vol. 3 , no. 1 , pp. $15-24,2020$.

[9] Sugiyono, Metode Penelitian Pendidikan Pendekatan Kuantitatif, kualitatif, dan R\&D. Bandung: Alfabeta, 2010.

[10] A. L. Hananto and A. Y. Rahman, "User Experience Measurement On Go-Jek Mobile App In Malang City," in 2018 Third International Conference on Informatics and Computing (ICIC), 2018, pp. 1-6. 